A list of Working Papers on the last pages

No. 265,1990

FINANCIAL INSTITUTIONS IN A

EUROPEAN MARKET FOR EXECUTIVE COMPETENCE

by

Gunnar Eliasson

To be published in Wihlborg, C.- Fratianni, M.- Willet, T.D. (eds.) "Financial Regulation and Monetary Arrangements after 1992", North-Holland, contributions to Economic Analysis Series. Amsterdam. 


\title{
FINANCIAL INSTITUTIONS IN A EUROPEAN MARKET FOR EXECU- TIVE COMPETENCE
}

\author{
Gunnar Eliasson
}

The Industrial Institute for Economic and Social Research (IUI), P.O.Box 5501, S-114 85 Stockholm, Sweden

\section{INTRODUCTION}

The ongoing deregulation of financial markets in Europe will induce substantial development of financial institutions. It is too early to tell whether EC markets will become securitized to the same degree as in the USA and in the UK. Continental European financial structures are traditionally more bank-oriented, and the banks in many countries are by ownership or by personal connection heavily involved in industry.

The thesis of this paper is that the organization of financial markets plays an important role in the economic growth process by influencing the allocation of, and the trading in individual and team competence in top level corporate management.

Competence is traded in (1) Internal Labor Markets, (2) External Labor Markets and (3) the Mergers and Acquisitions (M\&A) Market. Developments in EC after 1992 will influence the relative role of these markets. First, the international expansion of large firms is expanding the internal markets for high quality labor internationally. Second, improved external monitoring of high quality labor ("headhunting") is reducing the "lemon" characteristics of the external market for managerial talent, thus making firms increasingly exposed to being raided for such labor. Third, improved efficiency in the international M\&A market enables firms to acquire teams with competence that cannot be subdivided into individual competence. I argue that the growth of internal markets for high quality labor will be the most important vehicle for diffusing industrial knowledge between nations, that will also exercise a significant influence on the distribution of comparative advantages.

Financial markets play an important role not only because they facilitate or hinder takeovers, mergers and acquisitions but also because they monitor competence in firms and individuals. In these markets information is evaluated and incentives are provided for all modes of trade in individual and team competence.

The paper proceeds as follows. In Section 2 I discuss in more detail the concepts of individual and organizational competence and their role in the growth process within an essentially dynamic Schumpetarian theory of the firm. The view of the sources of competitiveness presented here contrasts sharply with conventional economic thinking underlying "industrial targeting" and trade policy arguments. This argument is developed in Section 3, where the European policy perspective is introduced.

The efficiency of alternative modes for trade and allocation of competence in internal and external markets are discussed in Section 4. I return thereafter in Section 5 to the link between the institutional structure of financial markets and the allocation of competence 
in the growth process. Section 6, finally, contains conclusions for the policy maker fearing that Europe is lagging behind the USA and Japan in industrial development and growth.

\section{ORGANIZATIONAL LEARNING AS THE SOURCE OF SUSTAINABLE COMPETITIVENESS IN FIRMS}

Quality embodied in goods traded in international markets is becoming the mark of distinction of advanced manufacturing firms and the source of technological competition. Rate of return targets imposed on firms by internationally integrated financial markets is increasing the intensity of competition. Results are evaluated in the stock markets, which, while still largely local are increasingly opening up to international competition.

The source of competitiveness of the individual firm no longer rests on cheap labor and technology embodied in new machines. Textile manufacturers learned by experience long ago that when technology became embodied in tradable machines, their earlier unique source of competitiveness also became tradable.

The source of sustainable competitiveness is embodied in individual or team competence within a firm. Sustainability requires that competence includes ability to continuously upgrade and renew technological and managerial competence. These static and dynamic aspects of competence are in the following summarized in the concept of the firm's organizational knowledge base or its organizational competence. Eliasson (1990a,b) contains a systematic presentation and a definition of this concept.

The nature of firm knowledge or competence is highly complex and not naturally tradable in markets. Allocation of firm competence means allocating people or teams of people. The dynamic aspect of sustainable competence has at least two components; competence to create new knowledge (innovation) and competence to receive and accumulate new knowledge created elsewhere (receiver competence). The latter has been almost completely forgotten in the literature. I use the concept organizational learning to describe the upgrading and renewal of competence, including both innovation and receiver competence.

The economic growth process cannot be understood unless we understand how people with competence are organized as hierarchies of competent teams making up the intellectual superstructure of firms. The use of organizational competence to create synergies, or economies of scale or scope among input factors, has important implications for the firm's organization in relation to imperfections in the markets for financial resources, labor, capital and products.

Economic theory is gradually rediscovering the intellectual dimension of economic activity, emphasized some 150 years ago by John Stuart Mill (1848), but later forgotten. There is a new awareness about, for example, the joint production characteristics of on-the-job learning exemplified by Arrow (1962a) and Rosen (1972). The business administration literature has paid increasing attention to "unique knowledge" or "ownership specific assets" as the source of competitiveness of firms. Selznick (1957), Williamson (1975) and Pelikan (1989) are three examples.

Rosen (1982) observes how superior competence in hierarchical positions can add value to all other factors of production through scale and scope economies, leading to very high 
rewards to top managers. Romer (1986) shows how scale economies that originate in the application of knowledge (an externality), can still be compatible with an interior solution in the static general equilibrium model, as long as the accumulation of such knowledge is associated with strongly diminishing returns.

There is also a growing literature on managerial and work incentives and performance in, for instance Lazear (1981), Harris and Holmström (1982), Holmström and Ricart i Costa (1986), Baker, Jensen and Murphy (1988), Jensen and Murphy (1990) and Campbell, Chan and Marino (1989). Most of this literature is cast in the asymmetric information mold, assuming that the capacity to diffuse managerial competence directly as information through markets is possible but costly. Non-tradable competence, on the other hand is the raison d'être for the existence of the firm and the source of the rent it enjoys in the capital market. Managerial and, more broadly, organizational competence can, however, be traded indirectly in the M\&A markets. Here I am particularly concerned with the potential for trade in organizational competence of the firm, especially organizational learning, the ability to constantly upgrade competence to sustain a superior rent earning capacity.

Competence for organizational learning is generally tacit and experimentally arrived at. Tacit implies that knowledge cannot be "blue-printed", but is embodied in individuals or teams. By definition it has no well defined reproduction value. Hence, it cannot be measured as other capital items. The stock-market would value it as the present value of its future rents. This market valuation, however, depends on the competence of market agents to assess the business situation of the firm. One cannot simply assume such markets to be perfect. This issue is discussed in Section 5.

Before turning to markets for indirect trade in organizational competence I contrast the above view of the firm and its source of competitive advantage with the conventional view providing the basis for industrial and trade policy.

\section{ECONOMIC LEARNING IN AN INTERNATIONAL PERSPECTIVE - THE EUROPEAN POLICY CONCERN}

\subsection{The European Industrial Policy Argument}

This section introduces the European industrial policy dimension. I begin with the misconceived economic argument behind "industrial targeting". In subsection 2 the requirements necessary to fulfill the vision of an advanced, dynamic European economy is discussed. Clearly organizational learning must provide the foundation for sustainable competitive advantages.

European industrial policy makers worry about export firms having difficulties providing jobs for blue collar workers. This tradition dates all the way back to the early seventies and it is reviewed in Eliasson (1984). At that time the advanced U.S. industrial technology was the source of concern. Today Japanese technology worries industrialists and policymakers. This concern was one of the reasons quoted for the Europe 1992 initiative, a "policy instrument" aimed at revitalizing European industry. Similar concerns about deficient factory-based technology, loss of competitiveness of manufacturing industry and deindustrialization have been voiced over the last decade in the U.S. (Singh 1987, Seal 
1990). Factory automation and more investment have become a frequently prescribed cure and economic arguments are made for "strategic targeting" of industrial and trade policy (see Dixit, 1987, Krugman, 1983).

Viewing tacit, team embodied knowledge accumulation as the source of firm competitiveness suggests that this orientation of policy thinking is misconceived. Inevitably, it takes us into a discussion of "industrial targeting". This concept is a polished-up version of the old "infant industry" argument rephrased on the basis of the so called "new international trade theory". It has been proposed as a protective device to shield U.S. firms from Japanese competition, while they achieve scale and work themselves up their learning curves, through R\&D spending, notably on factory automation. The "medication" is expressed in hardware processing or production functions terms.

In the general learning context, including organizational learning as defined here such advice becomes outright misleading. Empirically, it runs contrary to the Swedish experience of the 80s. The successful, giant Swedish multinationals, operating in markets for mature, technologically mature products, dominating the domestic Swedish economy emerged, contrary to all expert opinions, out of the debris, and the worried debate of the economically disorderly 70's. They did not base their success on hardware performance. They were probably helped by the devaluations of the Swedish krona, but primarily they conceived a new strategy of merging innovative product development with large scale, global production and marketing in a free trade environment (Eliasson, Bergholm et. al. 1985). They have been joining the EC-economy on their own, not bothering to wait for Swedish policy makers to decide.

As observed by Carlsson $(1979,1989)$ these firms have concentrated in the areas where their competence is superior by international standards. They have (Eliasson 1986, 1987) positioned themselves in the 80s on "three competitive legs": global international marketing, domestically based development of products and an internationally flexible and streamlined production organization, not focusing on large plant size but applying organizational competence in product development, marketing, and production organization in many production units worldwide.

The critical question for sustainability of these advantages is, however, what enables these firms to upgrade and renew their advantages. This is the issue of organizational learning.

Rephrased in terms of the European or the U.S. "competitiveness" problem, the source of productivity growth is the acquisition and upgrading of human based competence. A pertinent question to ask is, if an industry or a firm has allowed its human competence base to deteriorate, what makes management and policy-makers believe - as the industrial targeting proponents implicitly assume - that it will be able to revitalize it? If competence exists, why has it not been put to use before? Why is there a problem to begin with? Can a problem really be solved by those who have created it? Traditional economic theory underlying industrial targeting does not address these questions.

A problem of national competitiveness in an industry, by definition, means that more competent producers are operating from a base in other nations. If firms and people can move freely in response to economic incentives there should be no such problem. The upgrading of local competence can be achieved partly by allowing other firms to establish production in the problem nation, or by foreign acquisitions of low grade firms in that 
nation. The markets in which tradability in competence is most open are the $M \& A$ markets. This is also where we observe exactly this action already taking place. If it is hindered, local firms fail or have to be protected by trade barriers, like Italian and French automobile manufacturers. If the concern of the laggard nation is the welfare of, and jobs for its people, irrespective of centralistic political concerns, industrial targeting does not solve a real problem, although it might be motivated by concerns about loss of national political control of the economy.

\subsection{Europe 1992 and Organizational Learning}

What are the prospects for creating a viable "market" for industrial competence in Europe. I will find the answer, first of all in the opening up of financial markets (compare with the Smith-Walter paper in this volume), transacting freely across borders in shares, but also in the spontaneous development of EC markets for high quality labor.

Adam Smith (1776) has often been represented in literature (see e.g. King 1977) as hostile towards the joint stock company, and, hence, by modern standards towards big business. Similarly, Schumpeter (1942), following up on the Smithian theme, voiced strong concerns about the scientific corporate machine, that could routinize industrial $R \& D$ and enjoy extraordinary economies of scale. Once it had achieved a competitive edge this $R \& D$ machine would become the winner that took over the market, very much as the static general equilibrium model predicts will happen when scale economies are achieved. This is a puzzling worry on the part of two economists of towering proportions that made path breaking contributions to the theory of economic growth. They have been represented in literature out of context, however.

As Anderson and Tollison (1982) observe from rereading Smith (1776), the main worry of the latter was how to check monopoly formation among joint stock companies without reducing the incentives for them to use superior innovative ability. For Adam Smith, the moving force behind economic growth and the creation of wealth differences between nations was the market regime, or more specifically the extent to which it allowed for free competitive entry. Neither Smith nor Schumpeter, or for that matter Marshall (1890) would have suggested, as Arrow (1962b) did, to socialize innovative activity and distribute its results free of charge.

In my perspective entry should be interpreted broadly as a major force behind organizational learning. Entry requires competence and manifests itself in many ways, through international trade competition and in the M\&A markets. Above all, organizational learning to maintain a competitive edge, once acquired, requires continued direct participation in market competition with free entry and exit.

The global learning problem facing each firm and each nation can be illustrated within a simple model. In Figure 1 the competence structure in one country and industry at each point in time is represented by a "Salter curve" describing the productivity distribution of firms. Such distributions are usually thought of as linked to physical capital. I will link it to human-based competence, associated with firms, as in Eliasson and Lundberg (1990). Productivity may be measured by labor productivity as in Figure 1 or by total factor productivity.

(Figure 1 in about here). 
Potential competition in a market is characterized by a set of potential distributions as in Figure 1, including entry by foreign firms to the left in the figure. Depending upon the openness of markets, the local, say French, market for cars might have not only local producers, but also foreign manufacturers positioned along the curves as in the far right diagram. The best producers may be closed out by trade restrictions, thus reducing potential competition in the domestic market. The best foreign producers might nevertheless establish themselves in the market through foreign direct investment, boosting the upper, left hand corner of the local Salter distribution through infusion of competence. Firms might merge and recombine across national borders, reallocating competence to appropriate places, thus changing the shape of Salter curves in different markets. Almost all of this change is accomplished through reallocations of human competence in individuals and teams, much of it through the intermediation of financial markets, and some of it through individuals moving inside firms or in the international labor market.

If the supreme global performers on the far left in Figure 1 are shut out from a market through trade or establishment restrictions, then interior local producers may survive as in the middle diagram, leading to a welfare loss. The main point here is that the low end performers are also shut off from the learning experience of competing head on with the best global producers (Eliasson 1988c). In the longer run such policies, if enacted in a once rich nation, will be disastrous for productivity. In the longer term, when performance has been low for many years, and assets are cheap, these protected firms may be acquired by their competitors, then not for their competence, but rather for their acquirer to be able to take over their domestic market shares rapidly.

It is highly unlikely that even large political regions like the U.S. or Europe include the globally best performers in more than some markets. Other countries may have potentially promising candidates capable of learning if subjected to global competition with the best. Revitalizing Europe 1992 will have to allow for this competitive gamble and allow the market to select both the winners and the losers.

\section{ORGANIZATIONAL LEARNING AND TRADE IN COMPETENCE}

\subsection{General Issues}

The sustainability of a firm as a rent generating organization depends, as noted, on its ability to coordinate its internal activities efficiently at each point in time, and to organizationally learn efficiently over time. Firms that cannot balance these two tasks sooner or later fail and/or break up into smaller entities. The ability to achieve such viable integration of long-term (dynamic) and short-term (static) efficiency defines the organizational efficiency of the firm. This competence depends on how the steady filtering of competent people within the firm is organized and the ease by which new competence can be acquired in the market and integrated with the competent teams of the firm.

Trade and reallocation of competence discussed in this section can occur through: 
1. Internal labor markets within a corporation

2. External labor markets for managerial competence

3. The market for $M \& A$

While the first, internal market tends to strengthen the cohesive forces of a competent team, success in the other two markets requires receiver competence to work in favor of the firm. The acquisition of external competence can take place in external markets for labor and in the M\&A market. Two different types of competence acquisition are involved and there is an apparent substitutability between the two. While acquisition of new competence in the labor market can be gradual without disrupting the organization of the firm, acquisitions of new competence in the M\&A market can be swift, but also disruptive to the internal organization of the acquiring firm, often impairing its internal capacity to upgrade its competence in internal markets, and to keep the team together.

Two important aspects of competence allocation and organizational learning influence the relative efficiency of different modes for trade in competence. First, markets for competent labor may be imperfect, and the monitoring of competence characteristics costly. This explains the particular employer/employee relationships discussed within an asymmetric information, principal agent context by Greenwald (1986), Harris and Holmström (1982), Lazear (1981), and others. This problem becomes the dominant problem in establishing, running and reorganizing a firm with quality dominating all dimensions, and tacit knowledge being the typical competence characteristic. In brief, the market for the most critical quality input exhibits the characteristics of a market for lemons (Akerlof 1970). An important issue for alternative modes for trading in competence is the degree to which the lemon problem can be resolved.

The second important aspect of competence allocation is that experimental search becomes the optimal learning and allocation method for the firm due to the tacit nature of organizational competence. Experimental search requires an ability not only to coordinate, but also to identify mistakes early, and correct them efficiently (Eliasson 1988a,b). There are distinctly different characteristics associated with internal allocation of quality labor through the career and external allocation through the market.

\subsection{The Internal Labor Market - The Career}

The expansion of large firms (MNCs) internationally is expanding the internal markets for high quality management internationally, contributing to a more efficient international diffusion of industrial competence. The merger of ASEA and Brown Bovery provides interesting illustrations. The organization of the internal labor market, very much determines the capacity of the firm to earn a rent. As a consequence its effectiveness is part of the firm's organizational competence that is evaluated in financial markets.

The importance of the internal career is most obvious in large firms, notably in the large U.S. firms, with an internal educational organization to support the career. This formal organization is less extensive in European firms of similar size.

Since the method to identify talent and competence is experimental, the internal labor or career market carries a definite advantage from the point of view of monitoring career candidates for quality, compared to hiring in the external market. Internal recruitment, on the other hand, narrows the degree of variation in talent and experience compared to 
what is offered in the external market. This handicap can to some extent be overcome in large firms, notably large international firms. It is my conviction that the international integration of internal firm labor markets will constitute the most important internationalization of the markets for executive competence. Although in the short run M\&A markets, and internal markets can be seen as substitutes, they are in the longer run complementary, since the organization of effective, internal and international markets is a reason for, and a consequence of M\&A activity.

The development of markets for executive talent is illustrated by Glete (1989) who observes that executive labor markets were very thin in Sweden during the first half of the 20th century. Hence, very much as among specialized crafts, "manager dynasties" developed, the executive competence being passed on within families. As a result the resistance to changes in the orientation of the firm was great and monitoring of efficiency by owners was difficult. The prestige of executive managers was great. Tradability in and transferability of executive competence increased during the course of the 20th century, through the development of a career market in large firms and through the improved efficiency of external markets as well as through the links between financial institutions and corporations in, so called, industrial bank groups.

Glete (1989) studied the Wallenberg industrial bank group in particular. Such industrial bank groups do not build on risk diversification but on the organizational technique of earning a rent from allocating and integrating competence efficiently and also from achieving financial scale. Such groups incorporate a "quasi"internal market for very high level executive competence. It runs across several firms operating in many lines of business, with both domestic and foreign subsidiaries, offering a wide diversity of "corporate cultures", including a well rounded experience in international banking. Since such groups recombine all the time through acquisition and divestment of parts of firms, or entire firms, it is obvious that the internal labor market of such loosely structured groups perform a labor quality allocation function similar to that of a more decentralized M\&A market of the Anglo Saxon type. We return to this comparison when discussing financial market organization in Section 5.

An internal "career-market" for managerial and other types of competence requires investment of firm-specific resources in individuals. Highly efficient external labor markets implies high potential mobility and a trade-off between efficient internal and external allocation mechanisms for competence. As Lazear (1981) notes, there are contracts with delayed compensation schemes that can "tie" the individual to the corporation, but, since "slave contracts" are illegal, the characteristics of external markets for top-level competence requires discussion.

\subsection{Changing the Mind of the Firm through Competence Hiring in External Labor Markets}

The large internal pool of career candidates is the benefit of the large firm, and increasingly the large international firm. To acquire human talent the small firm normally has to reach out into the external labor market, at significantly higher search costs. If a (small) domestically based firm wants to go international the experience needed to do this successfully is usually not available inhouse. Even a big firm may have to reach out to acquire knowledge, when "it realizes" that its current competence base has grown too 
limited or obsolete. It is a common experience that a corporate organization problem can rarely be solved by the same group of people who allowed it to arise. The viability of a strong and capable owner is created by his or her mandade to change the mind of the top competent team through the removal of the existing team.

In interviews with top executives in large Swedish firms about such competence matters, the presence of directors from many other firms and close ties within an industrial bank group have been stressed. The capacity of the Board to overcome the inbreeding of competence common in closed and tightly run corporations has often been mentioned. Meyerson (1991) analyzes these issues in more detail.

Obviously, the trade in highly individualized and tacit human competence in open markets entails substantial transactions costs to overcome asymmetric information. "Traders" of various kinds have to be involved to reduce the risk of catching a high cost "lemon". The most common "trading institutions" are the "educational institutions" in the beginning of a candidate's career as emphasized, for example, by Sicherman and Galor (1990). "Old friends networks", "mentors" and other institutions have been created to establish the reputation needed for a viable trade in human embodied competence. As noted, the loosely structured industrial bank group arrangements can be seen as a "quasi"internalization of market transactions in managerial talent.

The new emerging traders in corporate talent, who may play a significant future role in the international talent trade, are the "headhunting firms". Headhunting is still a costly search activity reserved for the exclusive few. But such search is gradually becoming more systematically organized, allowing also for systematic knowledge accumulation within the search firms themselves. An internationalization of headhunting activities can be discerned, as noted by Jones (1989) and the exclusive nature of this activity will certainly break down national political and cultural barriers to executive mobility if the commercial incentives are sufficiently strong. An expansion of headhunting activities is clearly a substitute for internal markets in multinational firms.

Increased efficiency of internal organizational learning will make the firm a more attractive object for external talent raiding. External raiding requires a matching receiver competence, however. IBM did not succeed in incorporating Rolm competence into its organization. AT\&T has not been all that successful in making marketing people hired from IBM successful in the AT\&T environment. The acquisition of Sculley of Apple from Pepsi Cola by the headhunting firm Heidrick \& Struggles, has, however, so far been claimed to be a success according to Jones (1989). The headhunting firm Boyden, scored a similar success finding Geneen for ITT in 1959. The mixed record of headhunting indicates that external markets cannot become a perfect substitute for internal career markets. Thus, incentives for firms to invest in competence development will remain. The risks associated with such investments increase, however, as external market agents become increasingly efficient in identifying internally developed talent. A career at Electrolux has been quoted several times in my interviews as "the best management education available in Europe".

\subsection{Markets for M\&A Activity}

The third mode for trade and reallocation of organizational competence is M\&A activity. Smith and Walter document the importance of this mode in an international 
context in this volume. The major advantage of M\&A activity in my context is that it enables tacit knowledge and competence embodied in teams, as opposed to individuals to be reallocated. Like trade in external labor markets the effectiveness of this mechanism for allocation requires receiver comptence in both the acquiring and the acquired firm.

The rationale behind competence trade through M\&A activity is either that the acquiring firm is seeking an infusion of team competence or that it has competence that can be applied in another firm.

It was noted above that internal markets, external labor markets, and M\&A activity can be seen as substitutable modes for reallocation of competence and organizational learning. In the longer run internal markets and M\&A activity are also complements. The diverse, international firm probably offers the best internal, educational environment for executive competence. The most important complementarity between internal and external labor markets, on the one hand, and M\&A activity on the other, arises as a result of M\&A activity in the market for corporate control. Here the connection with financial markets and markets for competence and organizational learning is established.

The organizational knowledge base of the firm and its rent-earning ability is evaluated in financial markets. These markets signal information to incumbent management teams about the limits of their competence. They also provide incentives for the reallocation of organizational competence in firms. The effectiveness of markets for corporate control in performing this signalling and incentive functions, however, depends on their institutional structure. We turn to this issue next.

\section{FINANCIAL MARKET INSTITUTIONS AND THE ALLOCATION OF COMPE- TENCE}

\subsection{Alternative Institutional Structures}

Dahmén (1988) observed that each firm, as well as each bank internally performs the same three traditional functions of the credit market

(1) short-term lending (classical banking)

(2) long-term investment financing (the capital market)

(3) venture financing ("innovation")

Depending upon circumstances these three financing functions are performed in different mixes between the firms, the banks and the market. Sometimes all three "activities" are incorporated within large corporate hierarchies. Sometimes they are mostly performed in the market without the intermediation of banks. An intermediate form, sometimes called "industrial banks", or "industrial bank groups" of firms, more or less intimately tied to a bank through joint ownership arrangements were more common in the past. They still exist in Germany. In Sweden such groups are still functioning to some extent, although banks are not allowed to own corporations. Bank control of corporations is achieved through strong personal ties and common board members, and unequal voting rights. 
An efficient integration of all three activities - short term, long term and innovative - in the same monolithic organization of a large firm is very difficult, perhaps impossible. A conservative management style geared to short-term profit targeting tends to dominate at the expense of long-term innovative performance. The fragmented organization of many small firms in an efficient financial market, on the other hand, while perhaps innovative, normally lacks the benefits of large scale production and of efficient monitoring of venture activities.

The industrial banking group has sometimes been seen as the optimal organizational design to cope with the balancing of long and short term factors and the efficient monitoring of borrowers by, for example, Dahmén (1988), Eliasson (1990a), and Glete (1989). The ultimate controller of such groups has been the active owners who have taken on both the long-term responsibility and the ultimate selection of top competent people. Political concerns about the scope of individual or family wealth needed to support such a capitalist organization of the economic system and concerns about industrial concentration and monopoly formation have made it difficult in the last few decades to maintain this organization in many countries. In deregulated financial markets parts of such banking groups, often based on minority positions, have become exposed to take-overs. This threat is especially strong when the group allocates its resources and talent towards long-term ventures with delayed pay-offs relative to preferences revealed in stock market prices. Increased securitization of the international financial system therefore represents a consequence of deregulation that "threatens" the traditional industrial group with a bank at the center.

Rybczynski (1988) argues that in the securitized financial system

- rate of return monitoring and comparison of corporate activities become more efficient with improved information technology

- competitive entry and exit of financial institutions are facilitated, and

- exit of inefficient institutions is more efficiently enforced.

These mechanisms make it easier for investors to act rapidly, supplying finance to good prospects or pulling finance out of defunct operations from a distance. In the securitized market a larger number of agents are operating in the financial system, increasing the opportunities to obtain financing on a good, but risky idea. The junk bond market in the U.S. is one example of the changing performance characteristics of the financial system that directly influences the structure of the production system through the M\&A market. The important question is whether Europe will experience a development similar to the U.S.

The "softening" of manufacturing is another factor that facilitates competence mobility. Technology is moving increasingly in favor of smaller scale and more reliance on knowledge-based service production. As pointed out by Rybczynski (1988) such activities widen the competence gap between producers/investors and suppliers of finance, and require a new, more venturelike organization of financial markets. Rybczynski (1988) argues that the securitization of financial markets will facilitate the transition into a knowledge-based service economy, through integration of the knowledge allocation and 
financing functions through a multilayered, fragmented structure of specialist intermediaries thus reducing problems of asymmetric information while simplifying $M \& A$ and the financing of risky projects.

\subsection{Does the Market Give the Firm Time to Learn?}

The industrial banking group was, and may still be an efficient way to integrate the longterm innovative and the short-term operational functions within the same group, since organizational learning can proceed through quasi-internal markets for different types of competence. The weakness of this organization is that, without the threat of take-overs of parts of the group based on market valuation, competence development goes in the direction determined by a few dominant owners.

In the securitized system, on the other hand, M\&A activity is more prevalent with the consequence that corporate structures are less stable and more threatened by potential M\&A activity. The efficiency of organizational learning and the reallocation of competence therefore depends more on incentives provided by the two external modes of trading in competence. Incentives for individuals to invest in competence development depends on the returns that can be obtained in external labor markets, while owners of firms would invest in organizational learning if the M\&A market provides a satisfactory return on such investment.

Do labor and financial markets give the firm time to develop an efficient organizational knowledge base, or is the securitization creating "markets failures" in the long run? The detachment of financial agents in the market system from direct involvement in production decisions means that less effort and less competence are put to use by owners to actually remedy a distressed corporate situation. Owners sell off and leave rather than solve the problem. ${ }^{1}$ The industrial bank organization took care of the long term in the past. Rybczynski (1988) argues that in the securitized system competition will see to it that if there is a long-term merit to a project there will be some, among a large number of financial intermediaries, who understand that. The critical counterarguement would be that project evaluation requires evaluation of competence that is inherently tacit. Therefore the relevant information of insiders within the competent team of the business organization, required for competent valuation of the firm, cannot be available in the market (Eliasson 1988b, 1990a). ${ }^{2}$ If such insider competence is not allowed to influence the market valuation of the firm its assets will be undervalued and outsiders without the necessary competence to understand the organizational learning process would be able

1 Other arguments for a short-term bias in decentralized makers characterized by asymmetric information is found in, for instance, Stein (1988).

${ }^{2}$ Human capital theory suffers from the same problem. With tacit knowledge embodied in individuals or teams (firms) stable earnings functions do not exist and external market valuation of capital becomes imperfect. 
to take control and interrupt the organizational learning process, hence reducing the knowledge capital residing in the group as a whole. The market would not give the firm time to learn. To achieve the previous efficiency of long-term organizational learning compensatory mechanisms would have to exist to acquire the necessary competence externally through direct hiring in the labor market and/or through acquisition of competent teams in the M\&A market. Empirical evidence would suggest that firms lack the receiver competence for such external learning. Its tacit character may even make it impossible to acquire externally (Eliasson 1990a,b).

Some additional observations can be made about the securitized market oriented system. The more innovative a firm, the larger its propensity to fail and the more important that institutions exist that can understand the innovation potential and take on the long term risks needed in the financing of innovative activity. The developed securitized system will in principle be able to spread the financial risks and (through its diversity) mobilize the necessary evaluation competence. However, the greater the ambition to aim for the small probability of a large success, the more important it is for the innovator to be able to appropriate its innovation rent, i.e. to prevent imitations and to prevent the financial system from appropriating too large a share of the rent from a successful innovation. These observations point to the growing importance of large scale organizational technique in creating, protecting and rapidly commercializing innovations in advanced industrial nations, while at the same time effectively minimizing the incurred experimental costs, i.e. the costs of mistakes. The latter corrective function is only efficiently accomplished through competition in financial markets, and the securitized market should be most efficient in that respect.

However, in so far as it is true that the creative, innovative activity cannot be efficiently organized within large firms with the financial capacity to pursue long term goals, a particular organizational structure must develop in advanced industrial nations which both effectively promotes innovative work in small firms and effectively cashes in on innovations through rapid, large scale commercialization. Such firms, to succeed in the longer term must also possess a competence to identify and correct mistakes faster than the market does it. U.S. manufacturing firms seem to have been slow in learning this competence, being the first to be hit by early securitization of financial markets. Since securitization is such a strong force it will also unavoidably be forced upon the European financial systems, making it even more imperative that European firms and markets rapidly build the organizational competence to effectively cope with both innovation and large scale commercialization.

One solution could be that small firms specialize in innovations. The innovative firm is then acquired in the market by a large firm that is specialized in bringing innovations from the pilot to large industrial scale. In the small scale end of the innovative activity large learning costs will be incurred through frequent failure. Expected returns on innovative activity must then be very high to compensate for the risk. The bulk of resource use, including large scale risktaking will be managed in the large corporation with an entirely different organizational technique. Again, this requires the receiver competence to implement the new innovative competence in an entirely different production environment. Even though, as mentioned above, there may be principal obstacles to merging two very different tacit competence cultures successfully, without an 
extended learning period, it has been done. In fact, Japanese and Swedish firms have appeared as very successful organizers in the second, large scale end, drawing heavily on the generous output of the U.S. research establishment, to the detriment of a less implementation competent U.S. manufacturing industry. The future viability of the innovative machine of a country will, then, depend on the development of efficient competitive markets for financing of such innovative output, allowing the innovators to survive through capturing a sufficiently large part of the value they create (Eliasson 1986).

\section{CONCLUSION}

The initial question asked was what are the economic consequences of financial market developments for a European market for executive competence. The task has been to define the nature of this competence and the way it can be diffused through markets. The impact of financial market developments on organizational learning including both the creation of new competence (innovation) and of the receiver competence to accommodate external knowledge determines how the new vision of a dynamic Europe will be realized.

The central problem addressed is what effects the securitization of European financial markets will have on industrial structure. The conclusion is that the force of securitization imposed from international financial markets is too strong to be countered by policy, and it should not be, since securitization carries with it many beneficial effects. There is, however, the risk that securitization will force a break up of certain corporate structures, like industrial bank groups, that have successfully promoted internal organizational learning and the long term perspective in Europe, notably in West Germany and in Sweden.

One question is whether this has implications for financial market regulation. Yes, it has. One implication is that the existence of such innovative combinations of firms and financial institutions in a securitized financial system requires that the market be capable of informal evaluation of assets, such that market values of competence be kept sufficiently high to avoid destructive raiding. This requires the presence of active insiders in the market (Eliasson 1990a) and the first task for the European regulator is to avoid importing U.S. insider regulation to Europe. It may also be wise to allow a certain measure of unequal voting rights and to taylor the rules regulating the interests of competent financial institutions and firms carefully. Europe in fact offers a large variety of such rules to learn from, before hasty regulation is introduced.

The policy problem facing politicians turns out not to be a national problem, and not even a European problem. The solution lies in diffusing the national definitions of economies. Europe is probably too narrow a definition of a successful economic area because the organizational competence residing within it is not sufficient to match the corresponding competence of the U.S. and Japanese firms universally. Hence, opening up Europe to the globally best performers in each field is the best way to an efficiently specialized Europe. Another critical problem is whether European firms possess the receiver competence needed to acquire lacking knowledge efficiently. If not, it maybe necessary to call in the Japanese and the U.S. firms to invest in Europe and to infuse their knowledge in their European subsidiaries. It may be instructive to recall that this is 
exactly what the Swedish king did in the 17 th century, when he realized that Sweden lacked the manufacturing competence needed for industrial development in those days to create a viable arms manufacturing industry. The king created the incentives needed to induce competent entrepreneurs and skilled workers to move to Sweden, notably from Wallo nia.

\section{REFERENCES}

Akerlof, G.A., (1970), The Market for "Lemons": Qualitative Uncertainty and the Market Mechanism, Quarterly Journal of Economics, Vol. 84 (August), pp. 488-500.

Anderson, G.M. and R.D. Tollison (1982), Adam Smith's Analysis of Joint-Stock Companies, $\underline{\text { Journal of }}$ Political Economy, Vol. 90 (December), pp. 1237-1256.

Arrow, K.J. (1962a), The Economic Implications of Learning by Doing, Review of Economic Studies, Vol. 29 (June), pp. 155-173.

(1962b), Economic Welfare and the Allocation of Resources for Inventions; in Nelson, R (ed), 1962, $\overline{R a t e}$ and Direction of Inventive Activity: Economic and Social Factors, NBER, Princeton University Press, Princeton.

Baker, G.P., M.C. Jensen, and K.J. Murphy (1988), Compensation and Incentives: Practice vs. Theory, Journal of Finance, Vol. XLIII, No. 3 (July), pp. 593-615.

Barnard, C.H. (1938), The Functions of the Executive, Harward University Press, Cambridge Mass. \& London, England.

Campbell, I.S., Y.S. Chan, and A.M. Marino (1989), "Incentive Contracts for Managers who Discover and Manage Investment Projects", Journal of Economic Behavior \& Organization, No. 12, pp. 353-364.

Carlsson, B. et al. (1979), Teknik och industristruktur - 70-talets ekonomiska kris i historisk belysning, IUI and IVA, Stockholm.

Carlsson, B. (1989), "The Evolution of Manufacturing Technology and its Impact on Industrial Structure", Small Business Economics, Vol. 1, No. 1, pp. 21-37.

Carmichael, L. (1983), "Firm-Specific Human Capital and Promotion Ladders", Bell Journal of Economics, Vol. 14, No. 1 (spring), pp. 251-258.

Dahmén, E. (1988), Entrepreneurial Activity. Banking and Finance, Historical Aspects and Theoretical Suggestions, IUI Working Paper No. 209, Stockholm.

Dixit, A. (1987), "Strategic Aspects of Trade Policy", in Bewley, T. (ed.), Awareness in Economic Theory, Cambridge University Press, Cambridge.

Eliasson, G. (1976), Business Economic Planning - theory practice, and comparison, John Wiley \& Son.

(1984), "The Micro-Foundations of Industrial Policies", in Jacquemin, A. (ed.), European Industry: Public Policy and Corporate Strategy, Oxford University Press. 
(1986), "Innovative Change, Dynamic Market Allocation and Long-Term Stability of Economic Growth", IUI Working Paper No. 156, to be published in David and Dosi, (eds.), Innovation and the Diffusion of Technology. Oxford University Press, Oxford. Forthcoming.

No. 32, Stockholm

(1987), Technological Competition in The Experimentally Organized Economy, IUI Research Report

(1988a), "Schumpeterian Innovation, Market Structure and the Stability of Industrial Development", in Hanusch, H. (ed.), Evolutionary Economics, Applications of Schumpeter's Ideas, Cambridge University Press.

(1988b), "Ägare, entreprenörer och kapitalmarknadens organisation - en teoretisk presentation och översikt" in Örtengren, J. et al., Expansion, awveckling och företagsvärdering i svensk industri, IUI, Stockholm.

(1988c), The International Firm: A Vehicle for Overcoming Barriers to Trade and a Global Intelligence Organization Diffusing the Notion of a Nation, IUI Working Paper No. 201, Stockholm.

(1990a), "The Firm as a Competent Team", Journal of Economic Behavior \& Organization, Vol.13, No. 3 (June), pp. 275-298.

(1990b), Business Competence, Organizational Learning and Economic Growth, paper presented to the 1990 Joseph A. Schumpeter Society Meeting, Virginia, USA, June 3-5, 1990. Also as IUI Working Paper No. 264.

Eliasson, G., F. Bergholm, E.Ch. Horwitz, and L. Jagrén, (1985), De svenska storföretagen - en studie av internationaliseringens konsekvenser för den svenska ekonomin (The Giant Swedish Multinationals - a study on the consequences for the Swedish economy of Business internationalization), IUI, Stockholm.

Eliasson, G. and O. Granstrand (1985), Venture Capital and Management - a study of venture development units in four Swedish firms, mimeo, IUI.

Eliasson, G. and L. Lundberg (1990), The Creation of the EC Internal Market and Its Effects on the Competitiveness of Producers in Other Industrial Economies; in Siebert, H. and Mohr, J.C.B. (eds.), The Completion of the Internal Market Symposium 1989. Also as IUI Booklet No. 263, Stockholm.

Glete, J. (1989), "Long-term Firm Growth and Ownership Organization", Journal of Economic Behavior \& Organization, Vol. 12, No. 3 (December).

Granstrand, O. and S. Sjölander (1990), The Acquisition of Technology and Small Firms by Large Firms. Paper presented at the IUI Conference "Markets for Innovation, Ownership and Control", Saltsjöbaden, Stockholm, 1988. Published in Journal of Economic Behavior and Organization Vol. 13, No. 3 (June).

Greenwald, B. (1986), "Adverse Selection in the Labor Market", Review of Economic Studies, Vol. 53, pp. 325-347.

Harris, M. and B. Holmström (1982), "A Theory of Wage Dynamics", Review of Economic Studies, Vol.XLIX, pp. 313-333.

Holmström, B. and J.E. Ricart i Costa (1986), "Managerial Incentives and Capital Management", Quarterly Journal of Economics, Vol. CI, Issue 4, November. 
Jensen, M.C. and K.J. Murphy (1990), "Performance Pay and Top Management Incentives", Journal of Political Economy, Vol. 98, No. 2 (April), pp. 225-265.

Jones, S. (1989), The Headhunting Business, Macmillan, London.

King, M. (1977), Public Policy and the Corporation, Chapman and Hall, London.

Krugman, P.R. (1983), Targeted Industrial Policies: Theory and Evidence; Industrial Change and Public Policy symposium sponsored by the Federal Research Bank of Kansas City.

Lazear, E.P. (1981), "Agency, Earnings Profiles, Productivity and Hours Restrictions", American Economic Review, Vol. 71, No. 4, pp. 606-620.

Locke, R.R. (1989), Management and Higher Education since 1990 - The Influence of America and Japan on West Germany, Great Britain and France, Cambridge University press, Cambridge, New York etc.

Marshall, A. (1890), Principles of Economics, Macmillan, London.

Meyerson, E. (1991), Recruitment Processes for Leadership, Internal Dynamics and External Control, forthcoming doctoral thesis 1991, IUI Stockholm.

Mill, J.S. (1948), Principles of Political Economy with Some of Their Applications to Social Philosophy, London.

Murnane, R.J. and R.R. Nelson, (1984), "Production and Innovation when Techniques are Tacit: The Case of Education", Journal of Economic Behavior \& Organization, Vol. 5, Nos. 3-4 (Sept.-Dec.).

O’Brian, D.P. (1990), "Marshall's Industrial Analysis", Scottish Journal of Political Economics, Vol. 37, No.1 (Febr.).

Pelikan, P. (1989), "Evolution, Economic Competence, and the Market for Corporate Control", Journal of Economic Behavior \& Organization, Vol. 12, No. 3 (December), pp. 279-303.

Pratten, C. (1976), A Comparison of the Performance of Swedish and UK Companies, Cambridge University Press, Cambridge.

Ricart i Costa (1988), "Managerial Task Assignment and Promotion", Econometrica, Vol. 56. No. 2, (March) pp.449-466.

Romer, P.M. (1986), "Growth Based on Increasing Returns and Long-term Growth", Journal of Political Economy, Vol. 94, No. 5 (October), pp. 1002-1037.

Rosen, S. (1972), "Learning by Experience as Joint Production", Quarterly Journal of Economics, Vol. LXXXVI, No. 3, (Aug.), pp. 366-382.

(1981), "The Economics of Super Stars", American Economic Review, Vol. 71, No. 5.

pp. 311-323.

(1982), "Authority, Control and The Distribution of Earnings", Bell Journal of Economics, (Autumn), 
Rybczynski, T. (1988), Innovative Activity and Venture Financing; Access to Markets and Opportunities in Japan, the U.S. and Europe, IUI Working Paper No. 216, Stockholm. Forthcoming in Eliasson, Day, and Wihlborg (eds.) Markets for Innovation. Ownership and Control, IUI.

Schumpeter, J. (1942), Capitalism, Socialism and Democracy, Harper \& Row, New York.

Seal, W.B. (1990), "Deindustrialization and Business Organization: an institutionalist critique of the natural selection analogy", Cambridge Journal of Economics, Vol. 14, pp. 267-275.

Selznick, P. (1957), Leadership in Administration, Harper \& Row, New York.

Selznick, P. (1957), "Leadership in Administration", New York: Harper \& Row.

Sicherman, N. and O. Galor (1990), "A Theory of Career Mobility", Journal of Political Economy, Vol. 98 No. 1, pp. 169-192.

Simon, H.A. (1955), "A Behavioral Model of Rational Choice", Quarterly Journal of Economics, Vol. 69, pp. 99-118.

Singh, A. (1987), "Manufacturing Deindustrialization", in Eatwell, Milgate and Newman (eds.) The New Palgrave, Macmillan, London, pp. 301-307.

Stein, J., 1988, "Takeover Threats and Mangerial Myopics", Journal of Political Economy, (Febr.), pp. 61-80.

Smith, A., (1776), An Inquiry into the Nature and Causes of the Wealth of Nations, Modern Library, New York 1937.

Spence, M. (1973), "Job Market Signaling", Quarterly Journal of Economics, Vol. 87 (Aug.), pp. 355-379.

Stafford, I.P. and M.O. Stobernack (1989), Manufacturing Wages and Hours: Do Trade and Technology Matter? Mimeo, Department of Economics, University of Michigan and Technische Universitet, Berlin.

Williamson, O.E. (1975), Markets and Hierarchies: Analysis and Antitrust Implications. A Study in the Economics of Internal Organization, Free Press, New York. 
Figure 1

Market integration and Salter curves

Labor

productivity

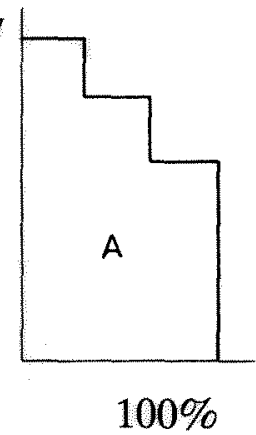

Foreign

firms

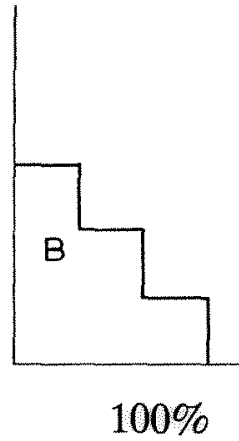

Local

firms

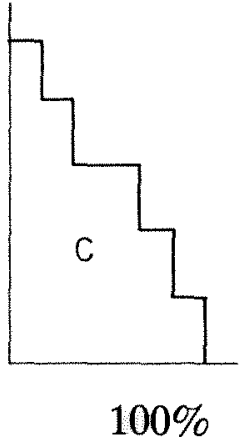

Local plus

Foreign firms supplying local market 